\section{Military and basic science offered more rapid growth}

Washington

PRESIDENT Reagan released his proposal for the 1985 federal budget last week, and left no doubts about the direction of his research and development policy: massive increases on the military side. The President proposed a record $\$ 33,852$ million for military research and development, an increase of 22 per cent over current spending. And while total civilian research and development spending would be held almost constant under the President's plan, its basic research components would increase by 10 per cent overall, with particularly generous treatment for the $\mathrm{Na}$ tional Science Foundation (NSF), the National Aeronautics and Space Administration (NASA) and the Department of Energy.

The new money for basic research is to come largely from deep cuts in applied research and - that particular bugaboo of the Reagan Administration's free-market philosophy - the engineering demonstration project. Energy projects, notably solar and fossil, but also (against the administration's will) the Clinch River fast breeder reactor, are the chief victims.

\section{Basic research}

Dr George Keyworth, the President's science adviser, has been taking pains to cast this budget as staunchly pro-science. For the first time, basic research is to receive a larger share of total non-military research appropriations than either applied research or development. Keyworth points with pride, too, to new funds for university instrumentation and training and to the fact that basic research support to universities has grown steadily during Reagan's term, reaching nearly $\$ 4,000$ million in this year's proposal, an increase of more than 25 per cent in real terms from the level where it had stagnated under the previous administration.

Last week also provided some apparently good news about industry's contribution to US research and development. According to a forecast released by the Battelle Memorial Institute, industrial support is expected to grow by 10 per cent in 1984 to a point where it makes up slightly over half of all US research and development expenditure, public and private.

The emphasis on basic academic research in the President's budget may well stifle complaints that the real increases have been reserved for military projects. If the Reagan budget is adopted, military research and development will have more than doubled (in nominal dollars) in just four years. Most of the military spending supports the new weapons systems to which the Reagan Administration has committed itself, including the Trident II and MX missiles and the B-1 bomber. A significant share of the new funds, however roughly $\$ 250$ million - is earmarked for the ballistic missile defence programme (also known as Strategic Defense Initiative or star wars).

\section{Science foundation}

On the civilian side, NSF is once again in line to be the big winner, with a 14.6 per cent increase in its budget to come on top of last year's 17 per cent increase. Mathematical and physical sciences and engineering would receive the lion's share of the new money, which includes $\$ 10$ million for the establishment of "Centers for CrossDisciplinary Research in Engineering"' to focus university research on problems faced by industry and to train graduate and undergraduate engineering students.

The NSF budget also includes a 22 per cent increase in support for scientific instrumentation - a total of $\$ 237$ million, $\$ 122$ million of which will be available under research grants to individual researchers with the remainder going to support university-based and national centres. Support for graduate students under research grants will increase by 15 per cent, allowing an additional 1,050 students to participate. And a new half-million-dollar experimental programme will provide women scientists with an opportunity to initiate research projects.

NSF has received the go-ahead to begin construction of the Very Long Baseline Array (VLBA), a network of radio telescopes across the United States. VLBA is expected to offer 100 times greater resolution than any existing radiotelescope.
A modest effort in supercomputing far short of what advocates had hoped for - is also included in NSF's proposed budget. No new hardware will be purchased, but $\$ 20$ million is to be made available to pay for access to existing supercomputers and to cover local user costs, such as terminals, software, networks and communication time. In a separate budget item, NSF plans to acquire a new supercomputer for the National Center for Atmospheric Research at Boulder, Colorado.

\section{Energy}

The Reagan philosophy is most evident in the proposed budget for the Department of Energy. While overall spending on research and development is to grow by only 1 per cent, basic research is to receive an 18 per cent increase.

Funds will be provided to start construction of the electron accelerator designed by the Southeastern Universities Research Association, which beat Argonne National Laboratory last year in a bitter political fight. Brookhaven National Laboratory, which last year lost another bitter fight to keep its illfated ISABELLE accelerator alive, is to receive its expected consolation prize of $\$ 15$ million for a tunnel that will link its existing van de Graaf accelerators and synchrotron, creating a new heavy-ion facility. A plan to incorporate the ISABELLE ring to create a massive relativistic heavy-ion machine is apparently still several years away.

The energy budget also provides support for initial studies of the Superconducting Super Collider concept in order to establish its feasibility and then to produce a specific design in several years.

Keyworth's pet project at Lawrence Berkeley Laboratory, the Center for Advanced Materials, has survived a year of criticism and, having lost its synchrotron advanced light source and the prefix "National", is to receive $\$ 11$ million with which to continue construction.

This year, the administration has taken a 
different approach to its perennial battle with Congress over the National Institutes of Health (NIH).

In past years, the tactic has been to ask for no increase for NIH in the knowledge that Congress in its rapture with that most popular of scientific agencies will add too much anyway. The administration has become increasingly concerned, however, that Congress's enthusiasm tends to be channelled into advocacy for narrow, disease-specific research, a tendency that threatens NIH's traditional freedom to support valuable but less glamorous basic research. "The "disease-of-the-month club' syndrome is no longer a joke", Keyworth said recently.

This year, the administration is proposing to give NIH an additional $\$ 102$ million, but specifically for areas of basic research that it believes have been neglected, such as neurobiology. Keyworth said he hopes that this proposal will "open a dialogue" with Congress and will give the administration a chance to air its views on the importance of basic research in the life sciences - particularly its role in underpinning US competitiveness in

biotechnology.

The Environmental Protection Agency, which in past years has felt the full weight of the administration's budget-cutting, is in for a modest increase this year in research funding. The news may not cheer the environmental lobby, however, as much of the new money will go for further studies of acid rain at a time when many including a panel that Keyworth himself assembled - have concluded that enough studies have already been done to support regulatory action, a step at which Reagan still baulks.

The National Oceanic and Atmospheric Administration (NOAA), the National Bureau of Standards (NBS) and the US Geological Survey are all in for major cuts in support for research and development on the principle that much of their research belongs in the private sector.

Particularly hard hit is NOAA, which is to lose a full one-third of its $\$ 242$ million research and development budget. And NBS's fire and building research centres are once again under threat of closure.

Stephen Budiansky

\section{Agricultural research}

\section{Towards grant competition}

\section{Washington}

THE US agricultural system, which has been repeatedly criticized for fostering mediocrity and neglecting basic science, is in for a major shake-up if the Reagan Administration has its way. The 1985 budget proposal would triple the size of the small programme of competitive grants for agricultural research, bringing it up to $\$ 50$ million, the maximum level currently authorized by law. The bulk of the new money would be reserved for basic research related to biotechnology.

Under the administration's proposal, most of the federal funds for sponsored research in agriculture would continue to be distributed to the country's land-grant colleges according to a state-by-state formula not involving peer review. But by rapidly expanding the competitive grants programme beyond its token level of $\$ 17$ million, the administration hopes to effect a major change in the way agricultural research is carried out. The expanded programme is expected to attract researchers at non-land-grant universities (among them the $I$ ading US basic research centres, such as Harvard and Stanford Universities) which are shut out from the formula-fund system. It may also bring some scientific rigour, by way of peer review, to a system often accused of drifting more and more to applied research of dubious scientific merit.

The new money, $£ 33$ million, is to come in part from an overall increase in the research budget of the Department of Agriculture (USDA) and in part from the phasing-out of the so-called "special grants", funds earmarked, usually by Congress, for specific projects.

Congress has baulked at past efforts to expand the competitive grants programme, which the smaller land-grant colleges in particular see as a threat to their assured support from the formula funds. This time things may be different. Many of the larger and scientifically more competitive landgrant institutions have broken ranks and have declared themselves in favour of an enlarged competitive grants programme. And both Secretary of Agriculture John Block and presidential science adviser George Keyworth have taken a personal interest in the programme.

Besides the new effort in biotechnology (which would receive $\$ 28.5$ million), the administration's proposal would establish a small effort in animal sciences (\$4.5 million); existing components in plant sciences (\$15 million) and human nutrition ( $\$ 2$ million) would continue. Approximately one-quarter of the competitive research funds would be expected to support graduate research assistants working under project grants.

The National Science Foundation's plant biology programme, which has traditionally taken up the slack in basic plant research, is also due for an increase under the President's budget - a 16 per cent rise, to $\$ 58$ million.

The USDA formula funding would grow by 2 per cent next year; and Department of Agriculture's own in-house research arm, the Agricultural Research Service, would receive a 3 per cent increase. Beltsville is not to be frozen out.

\section{Space science Panel's advice
ignored}

Washington

SPACE scientists are unlikely to give more than two cheers for the 1985 budget request for the National Aeronautics and Space Administration (NASA). The agency's basic research receives a hefty increase to $\$ 828$ million and three important new projects - the Mars Geoscience/Climatology Orbiter, the Upper Atmosphere Research Satellite and the Scatterometer experiment - have been given the go-ahead. But NASA has unexpectedly baulked at a plan to inject urgently needed new funds into university research groups.

The plan, devised jointly last year by university space scientists and NASA officials, carried the imprimatur of Frank McDonald, NASA's chief scientist. Yet neither of its chief recommendations found

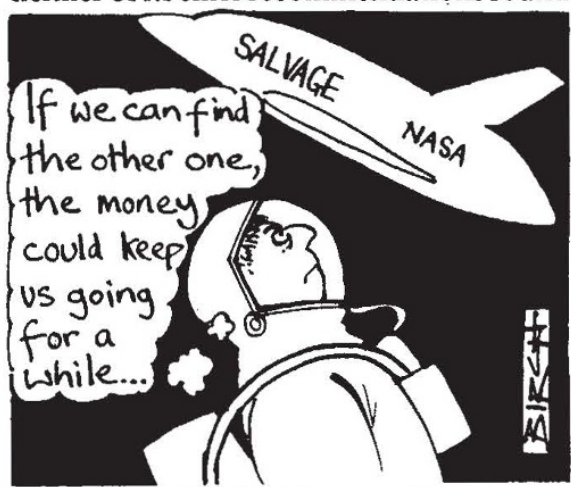

its way into the 1985 budget. One was to spend $\$ 11$ million extra a year for five years to buy new equipment for universities chiefly oscilloscopes, spectral analysers, computers, micro-ion probes and gas analysers. The other was to resurrect the NASA graduate fellowships that helped build up university space science in the 1960s.

Worse still, the budget contains no increase for basic research grants for university space science. Support for physics and astronomy is held at the same level as last year, while the amount for planetary science is reduced. Only one important recommendation of the McDonald report - more money to analyse mission data has been incorporated in the 1985 request. Funds for space shuttle operations are due to rise from $\$ 81$ million to $\$ 105$ million, but that is not expected to be enough to make shuttle science significantly cheaper or faster; since 1978 there has been a backlog of experiments waiting to fly.

NASA's overall budget increase is a scant $\$ 274$ million, or 4 per cent. That is enough, however, to keep alive major projects such as the Space Telescope (now renamed the Hubble Space Telescope), the Galileo mission to Jupiter and the Venus Radar Mapper. For 1985 only $\$ 150$ million is allocated for research on the proposed space station.

Peter David 